\title{
HOUND NEEDLEFISH, TYLOSURUS CROCODILUS (ACTINOPTERYGII: BELONIFORMES: BELONIDAE), IN OMANI WATERS
}

\author{
Juma M. AL-MAMRYa and Laith A. JAWAD ${ }^{\mathrm{b} *}$ \\ ${ }^{1}$ Marine Science and Fisheries Centre, Ministry of Agriculture and Fisheries, Muscat, Oman \\ ${ }^{2}$ Flat Bush, Manukau, Auckland 2016, New Zealand
}

Al-Mamry, J.M., Jawad, L. A. 2018. Hound needlefish, Tylosurus crocodilus (Actinopterygii: Beloniformes: Belonidae), in Omani waters. Acta Ichthyol. Piscat. 48 (3): 273-275.

\begin{abstract}
The hound needlefish, Tylosurus crocodilus (Péron et Lesueur, 1821) is a marine fish species associated with reefs. The first documented record of the hound needlefish, in Omani waters is based on a specimen of 750 $\mathrm{mm}$ total length collected by gill net on the coast of Muscat City, Oman. Morphometric and meristic data are provided.
\end{abstract}

Keywords: range extension, Belonidae, Sea of Oman, Arabian Sea

\section{INTRODUCTION}

Among the Middle East countries that were covered by major ichthyological surveys during the last decades of the 19th century is the Sultanate of Oman. During his studies, Boulenger $(1887,1889)$ succeeded to collect and preserve specimens from the Omani waters. This collection can be considered the first documented one from the Omani waters. Due to the unique biogeographical location of Oman, the fish fauna of this country has attracted scientists from around the world to undertake faunistic studies. Such activity has yielded an extensive literature (e.g., White and Barwani 1971, Fischer and Bianchi 1984, Al-Abdessalaam 1995, Randall 1995).

The family Belonidae covers 34 species representing 10 genera, with the genus Tylosurus represented by 9 valid species (Eschmeyer et al. 2018). Eight genera of the family are monotypic or contain only two or three species. Parin (1967) reviewed the family Belonidae exhaustively and gave detailed descriptions of each species. He stated that members of the genus Tylosurus are similar to those of Belone; however, the former differs in having a longer dorsal fin, no gill rakers, and in the presence of a thin black lateral keel on the caudal peduncle (Collette and Parin 1970, Collette 2003). Needlefishes differ from other members of the order in having both the upper and lower jaws extended into long beaks filled with sharp teeth (except in the neotenic Belonion). They are epipelagic, feeding near the surface, and are often observed leaping and skittering over the surface of the water.

In the Omani waters, there are four genera of the family Belonidae, Ablennes and Platybelone with one species each, Strongylura with 2 species, and Tylosurus with 3 species (Randall 1995).

The hound needlefish, Tylosurus crocodilus (Péron et Lesueur, 1821), is a marine species associated with reefs (Riede 2004). In the western Indian Ocean, it was found from the Red Sea and Arabian Gulf south to South Africa. (Cressey and Collette 1970, Assadi et al. 1997, Carpenter et al. 1997, Moravec and Ali 2005). The information given about the presence of this species from Omani waters in FishBase (Froese and Pauly 2018) is based on data from Randall (1995), but it is not clear where in the Omani waters he collected or observed specimen $/ \mathrm{s}$ of $T$. crocodilus. On the other hand, the records of T. crocodilus in GBIF (Global Biodiversity Information Facility) are only taken from Iran and the United Arab Emirates.

\section{MATERIAL AND METHODS}

The aim of the presently reported study was to confirm the occurrence of Tylosurus crocodilus in the Sea of Oman.

On 24 September 2017, a single specimen of the hound needlefish, $T$. crocodilus $(\mathrm{TL}=750 \mathrm{~mm}$ ) was collected from the coasts of Muscat City $\left(23^{\circ} 39^{\prime} 24^{\prime \prime} \mathrm{N}, 58^{\circ} 23^{\prime} 36.15^{\prime \prime} \mathrm{E}\right)$. The specimen was caught by fishermen using $30 \times 10 \mathrm{~m}$ drifting gill nets of $25 \mathrm{~mm}$ mesh size, and was subsequently measured with dial callipers to the nearest $0.1 \mathrm{~mm}$. The morphometric and meristic details of this species were presented in Table 1 including the same set of characters as presented earlier by Fischer and Bianchi (1984). The Catalog of fishes (Eschmeyer et al. 2018) was consulted for the taxonomic status and reference of the species. The specimen was kept frozen and deposited in the fish 
collection of the Marine Science and Fisheries Centre, Muscat, Oman, Catalogue No. OMMSFC 1334.

\section{RESULTS}

Our specimen of Tylosurus crocodilus (Fig. 1) is similar to the descriptions of this species given by Randall (1995) and Collette (2016). It has the following set of characters: absence of gill rakers; tongue rough; absence of teeth on vomer; presence of lobes on anterior parts of dorsal and anal fins; long pectoral and pelvic fins; presence of black keel on caudal peduncle area; deeply forked caudal fin, with lower lobe much longer than upper lobe; pelvic fin located midway between eye and caudal fin; there are 290 small scales in predorsal fin area; general body colouration dark green dorsally, silvery ventrally; dark blue bands on body sides. The morphometric and meristic characters are given in Table 1.

\section{DISCUSSION}

Fischer and Bianchi (1984) provided a set of characters for the other two species of the genus Tylosurus that show several morphological characters to separate them from Tylosurus crocodilus. The body in Tylosurus acus (Lacepède, 1803) is more slender; dorsal and anal fin lobes relatively low, contained $10.5-13.3$ and $9.7-11.7$ times in body length, respectively (5.4-10.6 and 5.5-8.0 times in $T$. crocodilus); pectoral and pelvic fins relatively short, contained 8.0-12.4 and 10.0-14.1 times in body length respectively (compared to 6.6 to 8.3 and 7.3-10.6 times in T. crocodilus); more dorsal fin rays, usually 25 (vs. usually 22 or 23 in T. crocodilus). Tylosurus choram (Rüppell, 1837) has a longer head, fitting 1.6-2 times in body length (vs. 2-2.6 times in T. crocodilus); on average fewer dorsal fin rays, 19-22, usually 21 or fewer (vs. 21-24 in T. crocodilus, usually 22 or more). Parin (1967)

Table 1

Morphometric and meristic characters of Tylosurus crocodilus collected from Muscat City, Sea of Oman

\begin{tabular}{lccc}
\hline \multirow{2}{*}{ Character } & \multicolumn{2}{c}{ Morphometric value } & Meristic value \\
\cline { 2 - 4 } & Absolute value $[\mathrm{mm}]$ & Relative value & - \\
\hline Total length (TL) & 750.0 & - & - \\
Standard length & 744.0 & 99.3 & - \\
Fork length & 74.7 & 99.6 & - \\
Head length & 9.0 & 12.0 & - \\
Eye diameter & 1.0 & 2.2 & - \\
Predorsal fin length & 350.0 & 46.7 & - \\
Postdorsal fin length & 352.8 & 47.0 & - \\
Prepectoral fin length & 192.0 & 25.6 & - \\
Prepelvic fin length & 423.0 & 56.4 & - \\
Pectoral fin length & 55.5 & 7.4 & - \\
Pelvic fin length & 67.5 & 9.0 & - \\
Preanal fin length & 434.4 & 57.9 & - \\
Postanal fin length & 438.2 & 58.4 & - \\
Body depth & 63.0 & 8.4 & - \\
Caudal peduncle length & 102.0 & 13.6 & - \\
Caudal peduncle depth & 16.5 & 2.2 & - \\
Height of dorsal fin lobe & 42.0 & 5.6 & - \\
Height of anal fin lobe & 49.5 & 6.6 & \\
Number of dorsal fin rays & & & - \\
Number of anal fin rays & & & - \\
Number of pectoral fin rays & & \\
\hline
\end{tabular}

Relative value is expressed as percentage of total length (\%TL).

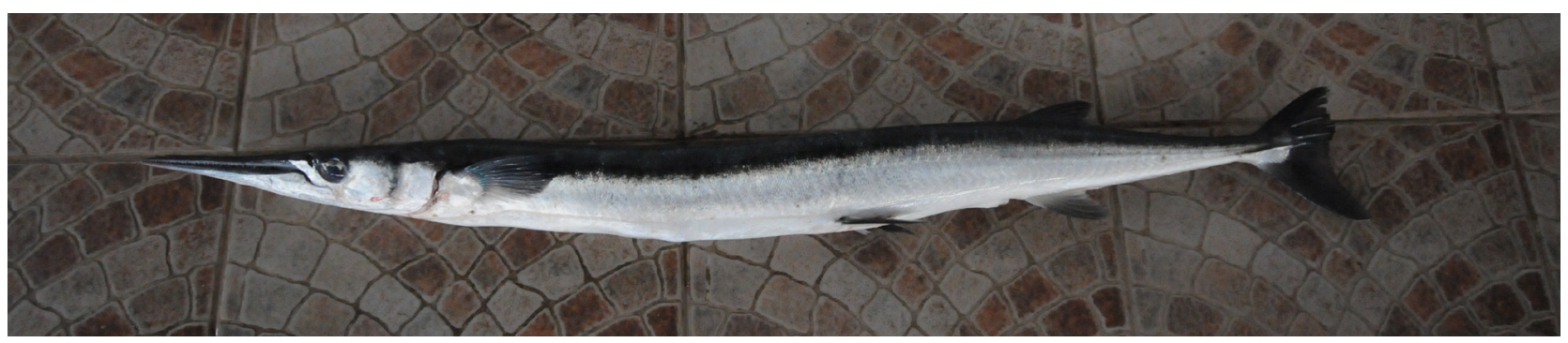

Fig. 1. Tylosurus crocodilus, $750 \mathrm{~mm}$ total length collected off the coast of Muscat City, Sea of Oman 
additionally noted that the diameter of the eye and the distance between the pelvic and anal fins are distinguishing characters between two species.

The presently reported specimen was smaller in total length $(750 \mathrm{~mm})$ than the maximum total length given for this species (1013 $\mathrm{mm} \mathrm{SL}$ ), but it corresponds to the upper limit of the mean total length $(90 \mathrm{~cm})$ (Collette 2016).

The available records show that the hound needlefish, T. crocodilus, is present in Omani waters (Cressey and Collette 1970, Randall 1995), although the main reference on fishes of Oman, Randall (1995), did not indicate where exactly in Oman it was observed. In addition, the photo used by Randall (1995) shows the specimen from the Maldives Islands. Therefore, the presently reported study represents the first documented record of $T$. crocodilus from the Sea of Oman and the first substantiated report on this species from the north-western Indian Ocean.

The examined specimen displays all characteristics of an adult individual, which possibly indicates the existence of an established population in the Sea of Oman, but such assumption needs to be corroborated through additional observations and collections of specimens of T. crocodilus from the Omani waters.

The absence of earlier confirmed records of T. crocodilus from Omani waters may be related to the lack of ichthyological studies and fishery surveys in the area.

\section{ACKNOWLEDGEMENTS}

We thank the Ministry of Fisheries Wealth, Marine Science and Fisheries Centre for the opportunity to use the technical facilities available in its laboratories. We are grateful to Kristiaan Hoedemakers, Royal Belgian Institute of Natural Sciences for reading the manuscript.

\section{REFERENCES}

Al-Abdessalaam T.J.S. 1995. Marine species of the Sultanate of Oman. Oman, Sultanate of Oman: Marine Science and Fisheries Centre, Ministry of Agriculture and Fisheries, Muscat, Oman.

Assadi H., Dehghani P., Jahanbakhsh M. 1997. Atlas of the Persian Gulf and the Sea of Oman fishes. Iranian Fisheries Research and Training Organization, Tehran, Iran.

Boulenger G.A. 1887. [3] An account of the fishes obtained by Surgeon-Major A.S.G. Jayakar at Muscat, east coast of Arabia. Proceedings of the Zoological Society of London 55 (4): 653-667. DOI: 10.1111/ j.1469-7998.1887.tb08159.x

Boulenger G.A. 1889. [3] Second account of the fishes obtained by Surgeon-Major A.S.G. Jayakar at Muscat, east coast of Arabia. Proceedings of the Zoological Society of London 57 (2): 236-245. DOI: 10.1111/ j.1469-7998.1889.tb06778.x
Carpenter K.E., Krupp F., Jones D.A., Zajonz U. 1997. Living marine resources of Kuwait, eastern Saudi Arabia, Bahrain, Qatar, and the United Arab Emirates. FAO species identification field guide for fishery purposes. Rome, FAO.

Collette B.B. 2003. Family Belonidae Bonaparte 1832; needlefishes. California Academy of Sciences, Annotated Checklists of Fishes No. 16.

Collette B.B. 2016. Belonidae. Pp. 1511-2342. In: Carpenter K.E., De Angelis N. (eds.) 2016. The living marine resources of the Eastern Central Atlantic. Volume 3: Bony fishes part 1 (Elopiformes to Scorpaeniformes). FAO Species Identification Guide for Fishery Purposes, Rome, FAO.

Collette B.B., Parin N.V. 1970. Needlefishes (Belonidae) of the eastern Atlantic Ocean. Atlantide Report No. 11.

Cressey R.F., Collette B.B. 1970. Copepods and needlefishes: A study in host-parasite relationships. Fishery Bulletin 68 (3): 347-432.

Eschmeyer W.N., Fricke R., van der Laan R. (eds.) 2018. Catalog of fishes: Genera, species, references. California Academy of Sciences, San Francisco, USA. [Accessed on 10 September 2018.] http:// researcharchive.calacademy.org/research/ichthyology/ catalog/fishcatmain.asp

Fischer W., Bianchi G. (eds.) 1984. FAO species identification sheets for fishery purposes. Western Indian Ocean (Fishing area 51). Volume 4. Family Scatophagidae to Trichiuridae. FAO, Rome.

Froese R., Pauly D. (eds.) 2018. FishBase. [Version 06/2018] www.fishbase.org

Moravec F., Ali A.H. 2005. Two new species of Philometra (Nematoda: Philometridae) from needlefishes (Belonidae) in Iraq, with a key to Philometra spp. parasitic in the host's subcutaneous tissue, fins and musculature. Folia Parasitologica 52 (3): 267-273. DOI: 10.14411/fp.2005.035

Parin N.V. 1967. Obzor morskih sarganov zapadnoj časti Tihogo i Indijskogo okeanov. [An overview of the marine needlefishes of the western parts of the Pacific and Indian oceans.] Trudy Instituta okeanologii Akademii Nauk SSSR 84 (1): 3-83 [In Russian.]

Randall J.E. 1995. Coastal fishes of Oman. University of Hawaii Press, Honolulu, HI, USA.

Riede K. 2004. Global register of migratory species: From global to regional scales. Final Report of the R\&D-Project 80805 081. Federal Agency for Nature Conservation, Bonn, Germany.

White A.W., Barwani M.A. 1971. Common sea fishes of the Arabian Gulf and Gulf of Oman. Volume 1. Trucial States Council, Dubai, United Arab Emirates.

Received: 25 January 2018

Accepted: 27 March 2018

Published electronically: 30 September 2018 